\title{
Spectra of mothers of premature children about the educative circle of culture
}

\author{
ESPECTROS DE MÃES DE PREMATUROS ACERCA DE CÍRCULO DE CULTURA \\ EDUCATIVO
}

\section{SPECTRA DE MADRES DE NIÑOS PREMATUROS SOBRE EL CÍRCULO EDUCATIVO DE LA CULTURA}

\section{Camila Santos do Couto', Milena Colares Tupinambá2, Aldecira Uchôa Monteiro Rangel ${ }^{3}$, Mirna Albuquerque Frota $^{4}$, Elis Mayre da Costa Silveira Martins ${ }^{5}$, Caroline Soares Nobre ${ }^{6}$, Fátima Luna Pinheiro Landim ${ }^{7}$}

\begin{abstract}
We sought to know the spectra of mothers of premature children regarding their experience with circle of culture of educational character and identifying the learning provided by the circle of culture about newborn care after hospital discharge. A descriptive study was performed in a hospital located in Fortaleza, Brazil. Three meetings of a circle of culture with 17 mothers of premature newborns were performed. The interpretation of the corpus was performed using thematic analysis. Emerged from the categories: maternal Experience in a circle of culture; promoted social support among mothers through the circle of culture; and Learning provided by the circle of culture. It was concluded that teaching parents during the hospitalization of the child should be held in a way to involve parents in the care of the newborn, provide moments of health education, opportunities for support and dialogue between professionals and family.
\end{abstract}

\section{DESCRIPTORS}

Neonatal Intensive Care

Health Education

Neonatal Nursing

\section{RESUMO}

Buscou-se conhecer os espectros de mães de prematuros acerca da vivência em círculo de cultura de caráter educativo e identificar o aprendizado proporcionado pelo círculo de cultura acerca dos cuidados com recém-nascido após alta hospitalar. Realizou-se estudo descritivo, em um hospital situado em Fortaleza-CE-Brasil. Foram realizadas três círculo de cultura com 17 mães de recém-nascido pré-termo. A interpretação do corpus foi realizada por meio da análise temática. Emergiram-se as categorias: Vivência materna em círculo de cultura; Apoio social promovido entre as mães por meio do círculo de cultura; e Aprendizado proporcionado no círculo de cultura. A capacitação dos pais durante o período de internação do filho deve ser realizada de modo a inserir os pais nos cuidados com o recém-nascido, proporcionar momentos de educação em saúde, ocasiões de apoio e diálogo entre os profissionais e a família.

\section{DESCRITORES}

Terapia Intensiva Neonatal

Educação em Saúde

Enfermagem Neonatal

\section{RESUMEN}

Buscamos conocer los espectros de las madres de niños prematuros con respecto a su experiencia con el círculo de la cultura de carácter educativo e identificar el aprendizaje proporcionado por el círculo de la cultura sobre el cuidado del recién nacido tras el alta hospitalaria. Un estudio descriptivo se realizó en un hospital ubicado en Fortaleza, Brasil. Se realizaron tres reuniones de un círculo de la cultura con 17 madres de prematuros recién nacidos. La interpretación del corpus se ha realizado mediante el análisis temático. Surgido de las categorías: Experiencia materna en un círculo de la cultura; Promovido el apoyo social entre las madres a través del círculo de la cultura; y El aprendizaje proporcionado por el círculo de la cultura. La enseñanza de los padres durante la hospitalización del niño debe ser recluido en una forma de involucrar a los padres en el cuidado del recién nacido, proporcionar momentos de educación para la salud, las oportunidades para el apoyo y el diálogo entre los profesionales y familiares.

\section{DESCRIPTORES}

Unidades de Cuidado Intensivo Neonatal Educación em Salud Enfermería Neonatal

${ }^{1}$ Nurse. Master in Public Health from the University of Fortaleza - Fortaleza, Ceará, Brazil. ${ }^{2}$ Nurse. Graduated from University of Fortaleza - Fortaleza, Ceará Brazil. ${ }^{3}$ Nurse. Master in Public Health from the University of Fortaleza - Fortaleza, Ceará, Brazil. ${ }^{4}$ Nurse. Post-PhD in Public Health by the Public Health Institute of the Federal University of Bahia. Professor, Master's program in Public Health, University of Fortaleza - Fortaleza, Ceará, Brazil. ${ }^{5}$ Nurse. Master in Public Health from the University of Fortaleza - Fortaleza, Ceará, Brazil. ${ }^{6}$ Nurse. Master in Public Health. Doctoral Student from the Public Health Institute of the Federal University of Bahia - Salvador, Bahia, Brazil. ${ }^{7}$ Nurse. Post-PhD in Public Health by the Public Health Institute of the Federal University of Bahia. Professor Master's program in Public Health, University of Fortaleza - Fortaleza, Ceará, Brazil. 


\section{INTRODUCTION}

The Neonatal Intensive Care Unit (NICU), technologically equipped, is considered a landmark of newborn preterm infants care (PTI). The investment in expert assistance of health professionals increases the survival rate of premature babies, but the follow-up of children after discharge, is still worrisome in the post-neonatal period. In this environment, other needs gain emphasis, such as family involvement in the care and maintenance of the quality of life ${ }^{(1)}$.

The Report of the World Health Organization (WHO), based on statistical modeling, estimated to occur fifteen million preterm births worldwide each year, ie, this corresponds to more than $10 \%$ of all births. The high prevalence of prematurity has social and economic implications: rising demand for the neonatal intensive treatment unit, in the short term, and costs of care required in the long term for individuals with sequels, which bear irreparable physical and mental health damages ${ }^{(2,3)}$.

In a way that the care of premature need to go beyond technology, so that parents get involved in a humane and participatory manner in the daily care, with explanatory dialogues that can be understood. The inclusion of the parents in the care of the newborn (NB) shows to be relevant, as this will be essential for survival of the newborn after discharge, given that the acquisition of knowledge and the development of parenting skills for home care after hospital discharge should be started on admission of the child to the neonatal unit ${ }^{(4)}$.

The scenario that consists of appliances, lights, noises, alarms and professionals, corroborates to the insecurity of mothers in relation to the child's life outside of that environment. This way the parents of a premature newborns suffer emotional damages, and pass through feelings of anxiety, guilt, fear and hope. Among the main triggering factors, besides prematurity, is the experience with hospitalization in a NICU. These anxieties are resolved through interaction by the triad consisting of parents, nursing staff and children ${ }^{(5,6)}$.

At the time of the discharge from hospital, families in some cases, and without specific preparation, are assigned to take care of premature children at home without them having received sufficient guidance for the specificity as demanded by the NB. These difficulties often occur due to problems with communication and formal support as provided by professionals, as they convey insufficient information and technical language, favoring misunderstanding by the parents ${ }^{(7)}$.

Nursing has core competence in guidance and support provided to the mother, as well as providing and encouraging the approach of the mother and child, making them confident to perform the same care at home ${ }^{(8)}$. In this sense, considering that newborns are at risk in the post-neonatal period, justified by prematurity, emerges the need of deepening about this theme.
Health education as a way to bring about change in the understanding of health, relating quality and commitment to life, brings changes in the attitudes to health promotion and disease prevention, in a way that health is not only seen as the responsibility of professional health, and the duty of the government $t^{(9)}$. That way, in view of the various ways of promoting health-related premature children, health education is fundamental for the production of continuous care, in order to instill the role of educator on the professional.

In this sense, the reorientation of strategies to improve survival and quality of life of premature infants at home involves several factors, among which the preparation of the parents in a liberating way for the care of preterm infants at home, stands out. From these considerations, it was aimed to know the spectra of mothers of preterm children regarding their experience with the circle of culture with educational characteristics, as well as identifying the learning provided by the circle of culture about newborn care after hospital discharge.

\section{METHOD}

The development of themes was guided by the study of descriptive qualitative approach, performed in the Neonatology Unit of a hospital in the city of Fortaleza, Ceará, Brazil. The subjects were mothers of preterm infants admitted to the neonatal unit. The following inclusion criteria were adopted: mothers of premature newborns born with a gestational age below 37 weeks, whose children were admitted to the neonatal unit without the use of antibiotics and that were not awaiting surgery. As an exclusion criteria was adopted: mothers with mental problems that would unable to participate in the study.

Data collection occurred through meetings of a circle of culture, which's wealth is based on the human tendency to build knowledge and form opinions and attitudes from the interaction with other individuals. The circle of culture consists of a strategy of liberating and problem-based education because there is no space for school seat education. This circle is a space for dialogue, composed of dialogue coordinators, group participants and reduced programming encoded in units of learning through debate. In short, the circle of culture can be defined as a space where all participants have the word and allowing the collective construction of knowledge.

This way, one understands the circle of culture as a space of educational activities in which the participants' involvement with the process of teaching and learning takes place, permeated of freedom so that one can express himself, intervene and establish horizontal relationships, in addition to experience collective actions and restructure concepts through a reflective process. ${ }^{(11)}$ The recruitment of participants began by delivering invitations for a week that preceded the meeting, with date and time previously established, and clarification about the study.
Spectra of mothers of premature children about the educative circle of culture Couto CS, Tupinambá MC, Rangel AUM, Frota MA, Martins EMCS, Nobre CS, Landim FLP 
To promote greater understanding between the participants and the researcher, a dynamic for presentation was held. From that moment the group was led by a guide with previously established themes. There were three meetings with a number of seventeen mothers in the period from August to November 2012. The meetings were made up by the hinge theme: Care of the premature newborn at home after hospital discharge.

The speeches were filmed, allowing an accurate description of speech and expression, after signing the Informed Consent Form (ICF), which declares the anonymity and the posterior destruction of the material after analysis of the corpus. For the development of the educational activity the problem-based education was used, also called conscientization, which seeks critical and reflective insert on the reality of man, so that there is a social transformation and exchange of experiences ${ }^{(12)}$.

Data recorded audio of the circles of culture were transcribed into Microsoft Word software from 2003 to 2007. The analysis and interpretation of the corpus were carried out by the technique of thematic analysis, which was used in order to organize them. The analysis is divided into three stages: pre-analysis, the recovery of the initial objectives of the study and the development of indicators to guide the final interpretation. Finally, the nuclei that compose the communication were identified, whose frequency or presence has significance for the research objective.

In order to preserve the identity of the mothers, was used a way of identifying with the use of alphanumeric characters, identified by the letters $M 1, M 2$, and so on according to the number of mothers in the study. The principles of bioethics, based on Resolution 244/12 of the National Health Council(13). Were respected as submitted and approved by the Research Ethics Committee of the General Hospital of Fortaleza, in Opinion Nr. 140307/12.

\section{RESULTS AND DISCUSSION}

From the reading and analysis of the data, the following core themes emerging from the categories were identified: maternal experience in the circle of culture; promoted social support among mothers through the circle of culture; and learning provided by the circle of culture.

\section{Maternal experience in the circle of culture}

The study subjects characterized the circles of culture as informal spaces for exchanging experiences in which they felt comfortable to express and clarify doubts. In the circle, details like the music and the interaction among the participants were proven.

"It was good, we talk, and conversate and it is not only listening to a person talking." (M14)
"At first I was embarrassed, but I like to hear my colleagues here talking, it felt like I was hearing my own doubts, someone asked what I wanted to know. I thought it was cool, the music they played calmed me and I began to think about all of this, but did not want to talk much, I'm ashamed." (M15)

"I'd never seen this stuff, the music, the way you talk and we can talk. Staying here is difficult, I'm feeling better. Able to talk with everyone things that interests us. I had many doubts, it has already greatly improved." (M16)

"It should happen more often. I liked the music, things that I wanted to know were spoken here, it was exactly what I wanted to know." (M17)

A survey of mothers of preterm infants found that learning time becomes beneficial for clarifying doubts, through questioning, that are expressed with less shyness. That is, in health education activities the mothers were more conducive to expose their uncertainties, apart from reducing the fear that some mothers have to speak out, hearing the speeches of the other mothers, they feel comfortable to express their views.

The practice of obtaining knowledge should not be imposed, but start from curiosity in the face of reality, implying invention and reinvention, through creativity and the intelligence existing in humans. ${ }^{(12)}$ Corroborating these data, randomized studies found that parents who received training on how to interact with premature newborns made a statistically significant difference in the knowledge of home care compared to the control group that received no training ${ }^{(15)}$.

\section{Promoted social support among mothers through the circle of culture}

Parents believe that prematurity of children is a particular experience, however, by joining the neonatal unit they are faced with the reality of many families, and then from the conviviality, they understand that they have companions in order to renew the strength to deal with the situation, improve the acceptance and overcome the frustrations $^{(16)}$.

"Here we can meet and exchange experiences. When you see that there are several similar cases, we do not feel so different." (M5)

"I see that everyone here is like me. Sometimes I feel guilty the baby was born that way, but when I see others talking I feel better." (M14)

"We get that little time close talking about how it will be when you get home with that boy." (M16)

"At first I was very ashamed, but after seeing everyone talking about the care of babies I was more at ease because almost everyone has the same questions and talks about the same things." (M17) 
"Sometimes I stay awake the whole night and when I get here it is that rush. I'm tired and I saw that the other mothers also suffer. I feel sad when I'm tired, I'm feeling guilty, today I saw that all mom's are going through it." (M18)

Social support promoted by the companions who have children hospitalized in the unit, was a strong ally to adaptation, as well as the moment of interaction between mothers and professionals did contribute by not being alone in this phase, as well as it allows us to understand that there are many mothers in a similar situation.

The need for support, help and exchange of experiences is highlighted. In general, they are supportive to each other and living together makes the perception of a whole context possible and not just the difficulties in a singular way. As from the maternal discourses, the presence of conceptions of guilt related to prematurity of the child stands out, in view that the mothers' pass possible causes, worries and significance for facts that occur during pregnancy that may be related to prematurity of the child(7).

"I'm feeling guilty, but today I saw that every mother goes
through that here [...]" (M13)

"Sometimes I feel guilty my baby was born that way, so tiny." (M8)

"It's too bad when I think that the fault he was born this way may be mine, it does a bad thing, it's hard to explain." (M3)

"I'm thinking it's because I fought a lot with my brother, I screamed, I ran. I was very nervous really." (M6)

"I think she was born that way because he made me very angry, I was shaking with anger." (M3)

Among a number of factors that influence the maternal guilt, we emphasize from the anguish, often resulting from preterm birth itself, to inadequate care, which results in an increase in concerns. Guilt can result from prematurity of the baby itself, a fact that has just mistakenly confirming the fears of mothers that they are not prepared for motherhood ${ }^{(1,6)}$.

\section{Learning provided at the circle of culture}

During routine in the NICU, the mom is more a spectator than active in the care process, thereby, she sees the newborn, but little participates in activities in relation to care. Furthermore, maternal exclusion is common, justified by performing invasive procedures, time of medical visits and reduced physical space ${ }^{(17)}$.

The news of the hospital discharge for parents whose children are hospitalized in the NICU is received with a feeling of freedom, accompanied with insecurity on the performance of the mother in caring for the child in unexpected situations that may happen ${ }^{(16)}$. In relation to insufficient preparation and information about care, it was noted that the bath and chocking are topics of doubt. This way, during the course of the circle of culture it was possible to address these issues.

\begin{abstract}
"Ah, the part of the bath. For me how many times he got dirty I gave him a bath and now I know I can not. Some care about clothing I also learned today." (M3)
\end{abstract}

\begin{abstract}
"I learned about the gagging and bathing. That one can pull the milk from the mouth of the baby if he choked, I did not know that." (M5)

"Now I know what to do if my child chokes and I had no idea."(M7)

"I learned that you have to breastfeed for 3 in 3 hours, that you have to put it to burp, that you can not wear perfume so not to give allergy."(M1)
\end{abstract}

"And i did not know that could put the clothes to dry in the sun, I thought it was wrong that way."(M7)

Empowering parents on care of the newborn is encouraged by the team of professionals. These can corroborate both the "curative" care process, and the identification and how to deal with emergency situations, distinguishing at what time it is necessary to take the child to the medical service.

Not always the lack of maternal preparation is caused by lack of information. In general, the unpreparedness occurs by dissemination of "erroneous" or incomplete information as commented by a neighbor or taught by an aunt or grandmother, culminated by an observed circle of culture and passed on between generations within the community.

\begin{abstract}
"It's not everything that we do not know, but some details. Because there is a lot we hear by word of mouth from the people and it is not that way. When he goes home, I would go and call everyone to see, but I cannot. I have to wait until he's more stronger and call a few people at a time, leaving the house airy."(M3)

"I had things that I would do with my son, because my mother told me what was right. Let the clothes dry in shade is one of them." (M7)
\end{abstract}

"My grandmother and the neighbor back home always say that if the baby's crying a lot, just to give him some tea and it will improve. Now I know I cannot do that. Only my milk and that's it." (M1)

It is evident that the information about the care of premature infants passed on to parents by professionals aim to strengthen the bond between parents and children, matched against, professionals tend to prioritize immediate assistance and thus neglect the magnitude of the educational activity and the preparation for hospital discharge ${ }^{(18,19)}$.

There are several precautions to be transmitted and taught, such as care related to visits, the use of the cup or
Spectra of mothers of premature children about the educative circle of culture Couto CS, Tupinambá MC, Rangel AUM, Frota MA, Martins EMCS, Nobre CS, Landim FLP 
spoon when difficulties during breastfeeding, the guidelines in case of choking and related facilities, the signs and symptoms that a newborn is not well and the actions to be undertaken in each case. These are more specifically related to prematurity care and have a highlighted key, this way the importance of being informed and taught by health professionals is emphasized ${ }^{(20)}$.

In a large part of the health services, there are difficulties and shortages of resources for achievement of these educational practices. The absence of physical, human and material resources put at risk this practice by making it dull, uninspiring and repetitive, for the professional and for the clientele. The use of teaching materials streamlines the activities of Health Education. Adding to these factors, democratic education is founded on the idea that man must discuss and analyze socializing problems. ${ }^{(6,12)}$ Therefore, the circle of discussion was held so that it can add to the experience of mothers by using an active, dialogical and participatory method.

One can identify the advantages related to the use of a focus group as a teaching on health promotion, as this interaction between mothers and professionals allows information related to caring for preterm infants to be exchanged, transmitted and taught in dialogue form, focusing on the major encountered difficulties, thereby reducing uncertainty and anxiety.

\section{REFERENCES}

1. Vasconcelos MGL, Leite AM, Scochi CGS. Significados atribuídos à vivência materna como acompanhante do recém-nascido pré-termo e de baixo peso. Rev Bras Saude Mater Infant. 2006;6(1):47-57.

2. World Health Organization. Born too Soon. The Global Action Report on Preterm Birth. Geneva: WHO; 2012.

3. Victora CG, Aquino EM, Leal MC, et al. Maternal and child health in Brazil: progress and challenges. Lancet. 2011;377(9780):1863-76.

4. Silva LJ, Silva LR, Christoffel MM. Tecnology and humanization of the neonatal intensive care unit: reflections in the context of the health-illness process. Rev Esc Enferm USP [online]. 2009;43(3):684-689.

5. Costa SAF, Santos MJA, Boas ASCV. Compreendendo a vivência da família com a internação do filho recém-nascido prematuro na UTI neonatal. Nursing. 2007;10(115):560-64.

6. Araujo BBM, Rodrigues BMRD. Mothers' experiences and perspectives regarding their premature infant's stay at the Neonatal Intensive Care Unit. Rev Esc Enferm USP [online]. 2010;44(4):865-867.

\section{CONCLUSION}

According to the study the spectra of mothers of preterms regarding their experience with circle of culture of educational character as well as the learning provided by the circle of culture about newborn care after hospital discharge is identified. Therefore, we highlight the influence of health education in the management with mothers of preterm infants, because education group activities leave mothers more comfortable to settle doubts and feelings, apart from providing interaction with the same, time for them to intuit as companions and, this way, share experiences and promoting learning.

Gaps in knowledge became evident about the care of mothers with premature newborns in the home environment. The provision of information on how to act and where to seek help is paramount; therefore, the highlight of the nurse in this learning process for the parents is understood.

The social support provided by partners who have children in the NICU showed up as a strong ally in adapting of the mother to the reality, reducing the uncertainty related to the experienced situation. During the circles of culture, the feelings of mothers who lack attention from health professionals were highlighted.

This way, the qualification of parents during the hospitalization of the child should be accomplished in order to insert them into the care of the newborn, provide moments of health education and offer support situations and dialogue among the professionals who assist the newborn and family.

7. Souza KMO, Ferreira SD. Vivência materna com o filho prematuro: refletindo sobre as dificuldades desse cuidado. REME Rev Min Enferm. 2010;14(2):159-165.

8. Costa SAF, Ribeiro CA, Borba RIH, et al. A experiência da família ao interagir com o recém-nascido prematuro no domicílio. Esc Anna Nery Rev Enferm. 2009;13(4):741-749.

9. Fonseca LMM, Scochi CGS, Rocha SMM, Leite AM. Cartilha educativa para orientação materna sobre os cuidados com o bebê prematuro. Rev Latinoam Enferm. 2004;12(1):65-75.

10. Freire P. Pedagogia do oprimido. 50ed. Rio de Janeiro: Paz e Terra. 2011.

11. Freire P. Pedagogia da autonomia: saberes necessários à prática educativa. 43ed. Rio de Janeiro: Paz e Terra. 2011.

12. Freire P. Educação como prática da liberdade. 30 ed. Rio de Janeiro: Paz e Terra, 2007.

13. Brasil. Ministério da Saúde; Conselho Nacional de Saúde, Resolução no 466 de 12 de Dez/2012. Diretrizes e Normas Regulamentadoras de Pesquisa envolvendo Seres Humanos. Brasília; 2013. 
14. Fonseca LMM, Góes FSN, Ferecini GM, et al. Inovação tecnológica no ensino da semiotécnica e semiologia em enfermagem neonatal: do desenvolvimento à utilização de um software educacional. Texto \& Contexto Enferm. 2009;18(3):549-558.

15. Prentince, M, Stainton, MC. The Effects of Developmental Care of Preterm Infantis on Women's Health and Family Life. Neonat Paediatr Child Health Nurs. 2004;7:4-12.

16. Guimarães GP, Monticelli M. A formação do apego pais/ recém-nascido pré-termo e/ou de baixo peso no método mãe-canguru: uma contribuição da enfermagem. Texto \& Contexto Enferm. 2007;4(16):626-635.
17. Gaíva MAM, Scochi CGS. A participação da família no cuidado ao prematuro em UTI Neonatal. Rev Bras Enferm. 2005;58(4):444-448.

18. Conz CA, Merighi MAB, Jesus MCP. Promoting affective attachment at the neonatal intensive care unit: a challenge for nurses. Rev Esc Enferm USP [online]. 2009;43(4):849-855.

19. Suzuki VF, Carmona EV, Lima MHM. Planning the hospital discharge of patients with diabetes: the construction of a proposal. Rev Esc Enferm USP [online]. 2011;45(2):527-32

20. Fonseca LMM, Scochi CGS. Cuidados com o bebê prematuro: orientações para a família. 2ª ed. Ribeirão Preto: FIERP; 2005. 